\title{
GeoMed 2017: visão mais profunda a partir de big data e pequenas áreas
}

Marilia Sá Carvalho 1

Maria de Fátima Pina 2

doi: 10.1590/0102-311X00172017

Este foi o tema do Congresso Internacional realizado no Porto, Portugal, em setembro de 2017: o GeoMed já em sua 10a edição. Ao longo dos 20 anos desde o primeiro evento, esse encontro vem se consolidando como o principal fórum de apresentação de novos métodos e abordagens voltados para revelar o papel do espaço, da geografia, do local e do ambiente nas questões da saúde pública. E mais uma vez, foi um encontro de excelência. Nesse sentido, o Congresso tem atraído não só estatísticos, como nas primeiras edições, mas também geógrafos, cientistas da computação e profissionais da área da saúde pública com interesse na discussão de novas metodologias de tratamento e análise espacial de dados complexos. Nessa edição, o número de participantes dobrou em relação à anterior, atraindo pesquisadores de 28 países, dos cinco continentes, com um grande equilíbrio entre as áreas: $37 \%$ da área de estatística, 27\% da saúde pública, 25\% das geociências e 11\% das ciências da computação.

Um aspecto a ser ressaltado é a evolução nos métodos e nas bases de dados. Por exemplo, num dos minicursos do pré-congresso, foi apresentada nova biblioteca no R (The R Foundation for Statistical Computing, Viena, Áustria; http://www.r-project.org) para a modelagem de dados espaciais. O outro minicurso foi voltado para a plataforma da Google - Google Earth Engine -, de acesso livre, que permite manipular e combinar informações obtidas por sensoriamento remoto, em escala planetária, viabilizando estudos que seriam impossíveis em ambiente de um computador isolado. Abordagens inovadoras no campo da vigilância à saúde foram foco de sessões temáticas e muitos pôsteres. A modelagem estatística, tradicionalmente o ponto mais forte do Congresso, também foi repleta de novidades: da análise de sobrevivência espacialmente condicionada, aos modelos espaço-temporais capazes de identificar tendências e aglomerados, tanto no espaço como no tempo, aliás, surtos epidêmicos como diriam os epidemiologistas 1 .

Mas o GeoMed também trouxe uma reflexão sobre as diretrizes gerais para os artigos com o foco na relação entre espaço geográfico e saúde que são submetidos ao CSP. Por um lado, evidencia-se a necessidade da elaboração de perguntas claras: por que a localização espacial deve ser investigada? Qual a hipótese? Muitas vezes recebemos artigos que se assemelham a exercícios acadêmicos, nos quais o uso de sistemas de informações geográficas (SIG) e alguma estatística espacial são usados inadequadamente, ou de maneira pouco
1 Editora.

2 Universidade do Porto, Porto, Portugal. 
clara para o leitor. Por outro lado, os métodos no campo avançaram. O que há 15 ou 20 anos atrás era a única possibilidade de análise espacial, por exemplo, detectar a presença de dependência espacial por meio de testes estatísticos, hoje em dia não há justificativa para limitar os estudos a estas técnicas, que não refletem o estado da arte e são insuficientes para responder às perguntas da pesquisa. É o equivalente a ignorar que se pode usar um modelo de regressão múltipla e estimar a força da associação, limitando-se a testar se médias de dois grupos diferem. Artigos de modelagem que considerem a localização espacial devem necessariamente ter perguntas e hipóteses claramente descritas na introdução. E o método deve ser adequado à pergunta. Na verdade, essa recomendação apenas expande as recomendações já explícitas para os artigos epidemiológicos de forma geral, resumidas nas instruções aos autores.

Também no campo da vigilância epidemiológica pudemos conhecer experiências muito instigantes, fazendo uso de ferramentas inovadoras. CSP tem interesse em receber artigos nessa linha, que possam responder a perguntas como: haveria alguma forma de detectar mais precocemente a epidemia de microcefalia? 2; como lidar com o atraso de notificação?; é possível usar as redes sociais para melhorar a predição de surtos 3 ?

A epidemiologia ambiental é por si só um tema de grande interesse. Mas, novamente, precisamos ir além da simples identificação da associação entre exposição e desfecho, por exemplo poluição, como fator de risco para as internações por problemas pulmonares. Isso já está demonstrado. Precisamos discutir a integração de múltiplas fontes de dados, de imagens obtidas por sensores a bordo de satélites a dados de estações locais, para melhorar a exatidão, a precisão e a resolução espacial das estimativas de poluentes. Precisamos avançar no conhecimento sobre os demais danos à saúde causados pela poluição 4 .

A interface geografia/saúde é antiga, é bem conhecido o mapa da cólera em Londres (Inglaterra) no século XIX. Vale resgatar também que nesse tema o Brasil teve grande participação do final da década de 1990 até meados da década seguinte 5. É do nosso interesse trazer para o CSP artigos com questões acerca do papel do ambiente sobre a saúde, sobre como melhorar nossa capacidade de detecção precoce de aglomerados espaço-temporais, sobre onde alocar serviços de saúde, sobre o acesso e a trajetória de pacientes, entre outros. O campo é vasto, interessante e relevante. 
1. Pina MF, editor. GeoMed 2017. International conference on spatial statistics, spatial epidemiology and spatial aspects of public health. http://www.i3s.up.pt/geomed2017/.

2. Barcellos C, Xavier DR, Pavão A, Boccolini C, Pedroso FPM, Romero D, et al. Increased hospitalizations for neuropathies as indicators of zika virus infection, according to health information system data, Brazil. Emerg Infect Dis 2016; 22:1894-9.

3. Marques-Toledo CA, Degener CM, Vinhal L, Coelho G, Meira W, Codeço CT, et al. Dengue prediction by the web: tweets are a useful tool for estimating and forecasting dengue at country and city level. PLoS Negl Trop Dis 2017; 11:e0005729.
4. Beil L. The list of diseases linked to air pollution is growing. Science News 2017; 192(5). https://www.sciencenews.org/article/list-dise ases-linked-air-pollution-growing.

5. Carvalho MS, Souza-Santos R. Análise de dados espaciais em saúde pública: métodos, problemas, perspectivas. Cad Saúde Pública 2005; 21:361-78 